Cereal Research Communications 43(2), pp. 295-306 (2015)

DOI: $10.1556 / C R C .2014 .0044$

First published online 4 February, 2015

\title{
Physical Properties and Chemical Characterization of Macro- and Micro-nutriments of Elite Blue Maize Hybrids (Zea mays L.)
}

\author{
D.A. URIAS-LUGO ${ }^{1}$, J.B. HerediA ${ }^{1}$, J.B. VALDEZ-TORRES ${ }^{1}$, M.D. MUY-RANGeL ${ }^{1}$, \\ S.O. SERNA-SALDIVAR ${ }^{2}$ and S. GARCÍA-LARA ${ }^{2}$ \\ ${ }^{1}$ Ciencia y Tecnología de Alimentos. Centro de Investigación en Alimentación y Desarrollo, \\ A. C. Carretera a El Dorado Km 5.5 Col. Campo El Diez, Culiacán, Sinaloa, México. CP 80110 \\ ${ }^{2}$ Escuela de Biotecnología y Alimentos. Centro de Biotecnología FEMSA. Tecnológico de Monterrey. \\ Av. Eugenio Garza Sada 2501 Sur. Monterrey, Nuevo León, México. CP 64849 \\ (Received 27 March 2014; accepted 24 July 2014; \\ Communicated by H. Grausgruber)
}

\begin{abstract}
Five elite blue maize hybrids and two blue maize landraces were evaluated for various quality characteristics. Hybrids showed physical characteristics demanded by dry-millers and tortilla processors: above $290 \mathrm{~g}$ in one hundred-kernel weight test, higher test weight $\left(76.1-78.5 \mathrm{~kg} \mathrm{hl}^{-1}\right)$ and lower flotation index (22-61\%). Hybrid maize $613 \times 27(9.9 \%)$ and $611 \times 8(9.5 \%)$ contained the highest protein. Potassium, magnesium, manganese and zinc contents of hybrid maize were higher than landraces by $15,30,55$ and $41 \%$, respectively. Nutrimental profile showed linoleic acid contents above $50 \%$ in $503 \times 67,613 \times 27$ and $611 \times$ 8 hybrid samples. Lysine levels of landraces and hybrids $503 \times 67\left(33.9 \mathrm{~g} \mathrm{~kg}^{-1}\right.$ protein $)$ and 631 $\times 27$ (31.7 $\mathrm{g} \mathrm{kg}^{-1}$ protein) were higher than reported for regular white corn $\left(27 \mathrm{~g} \mathrm{~kg}^{-1}\right.$ protein), as well as the highest tryptophan levels for Chalqueno $\left(6.0 \mathrm{~g} \mathrm{~kg}^{-1}\right.$ protein) and hybrid $503 \times 67$ $\left(6.9 \mathrm{~g} \mathrm{~kg}^{-1}\right.$ protein). Highest protein quality based on its digestibility was found in hybrid $503 \times$ 67. Results indicated that elite blue maize hybrids could be an important source of nutrimental compounds with potential for functional food industries.
\end{abstract}

Keywords: blue maize, hybrid maize, landraces, nutriments

\section{Introduction}

In recent years, the demand for functional foods has increased because the current scientific research proves its close relationship with health; such is the case of pigmented maize (Pandey et al. 2010). Among the most common are yellow, orange, red, purple, black and blue maize. While provitamin A from yellow and orange maize plays an important role in human diets, purple, red, black and blue maize are mainly characterized for their anthocyanin content (Žilić et al. 2012). Particularly, blue maize (Zea mays L.) is a special pigmented maize with blue aleurone layer covering the white endosperm. It has been tra-

*Corresponding author; E-mail: jbheredia@ciad.mx; Phone: +52 667760 5536, Fax: +52 6677605537 
ditionally dry-milled for production of flours or meals and also used for tortilla chips and table tortillas. It has high levels of anthocyanins and other phenolics with proven nutraceutical properties (Serna-Saldivar 2010). Also, in South America, principally in Peru and Bolivia a traditional drink, "chicha morada", is produced from purple maize. In Europe, some new attractive healthy food have been developed in order to satisfy consumers' demands, such as coloured popcorn and polenta rich in anthocyanins (Lago et al. 2013, 2014). Generally, maize landrace endosperm is less dense and softer compared to white maize counterparts as well as more susceptible to pest damage (Serna-Saldivar 2010). Moreover, yield of landraces $\left(2.5\right.$ to $\left.3 \mathrm{t} \mathrm{ha}^{-1}\right)$ is generally lower than that of hybrid corn grown in northwest Mexico (Sinaloa state) with an average yield over $10 \mathrm{tha}^{-1}$ (García-Lara et al. 2012). Per capita consumption of maize in Mexico exceeds $120 \mathrm{~kg}$ per year, which indicates that a diet based on an intake of 2000 calories, carbohydrate and fat content of corn provides more than a half of the calories and about $45 \%$ of protein from the recommended dietary intake for Mexicans (FAOSTAT 2013). Solid scientific evidence confirms that besides of supplying major nutrients, blue maize also contains biologically active components beneficial to health, which offer the possibility of reducing the risk of chronic degenerative diseases and improve quality of life (Shankar and Prasad 1998; Feng et al. 2002; Bódi et al. 2008; Serna-Saldivar and Abril 2011; García-Lara et al. 2012). This is the case of some minerals and unsaturated fatty acids. Zinc is an essential trace element and plays a major role in cell division. It is important for tissue repair, wound healing and normal growth immunity (Shankar and Prasad 1998). Also, high zinc accumulation inhibits the proliferation and induces apoptosis of prostate cancer cells (Feng et al. 2002). Moreover, fortified breads with polyunsaturated fatty acids offer a protective effect of cell membrane oxidation (Serna-Saldivar and Abril 2011). Therefore blue maize is considered as functional food (Harrigan et al. 2007; Castañeda-Ovando et al. 2009).

However, most of the blue maize research is focused on blue maize highland landraces genotypes and very little nutrimental information is known about hybrid types in the same environment. Blue maize hybrids have been only recently available for tropical (Beltran et al. 2001) and subtropical environments (Urias-Peraldí et al. 2013). Hybridization offers the opportunity to plant high yielding blue hybrids that preserve nutrimental properties associated to regular counterparts and also contain micro-nutriments that impart additional antioxidant and health promoting properties. The aim of this research was to evaluate the potential of elite blue maize hybrids in the food and functional industry as a natural source of nutriments.

\section{Materials and Methods}

\section{Maize genotypes}

Five blue hybrid maize genotypes (named as $503 \times 27,503 \times 67,613 \times 27,611 \times 8$ and $631 \times 27)$ were acquired from the Genetic Improvement Program of Hybrids Lobo Company (Chihuahua, Mexico). The hybrid genotypes were adapted to highlands of temperate environments of Mexico (Queretaro and Chihuahua, Mexico). Kernels of Chalqueno and 
conico landraces which were cultivated in highlands of Mexico (Puebla and Mexico City, respectively) were used as references. This landraces were kindly donated by National Research Institute of Forestry, Agriculture and Livestock (INIFAP) Corn Quality Laboratory (Mexico). Corn samples were grown during 2010 and kept at $4{ }^{\circ} \mathrm{C}$ until analysis. Previous to analysis the corn sample was ground in a $\mathrm{G} \times 4100$ coffee grinder (Krups, China). Whole and ground kernels were stored at $-20^{\circ} \mathrm{C}$ prior to analysis.

\section{Physical properties}

Kernel test weight was determined using the Winchester Bushel Meter (Seedburo Equipment Co., Chicago, IL) according to method 55-10 of the AACC (2000) and thousand-kernel weight by weighing 1000 randomly selected kernels. To determine kernel size 6.7, 5.6 and $4.75 \mathrm{~mm}$ sieves were used. Width, length and thickness kernel-dimensions were measured using an IP 65 digital micrometer (Mitutoyo, Japan). Flotation index (FI) was determined according to the original procedure reported by Wichser (1961) and expressed as percentage of floating kernels on an aqueous solution of sodium nitrate with a specific weight of $1.25 \mathrm{~g} \mathrm{~cm}^{-3}$ at $35^{\circ} \mathrm{C}$ (Emam et al. 1981). L*, a*, b* and chroma flour-parameters were measured using a CR-300 colorimeter (Minolta, Japan). For kernel-composition determination, $50 \mathrm{~g}$ of kernels were soaked during $10 \mathrm{~min}$ in $100 \mathrm{ml}$ of water. The wet kernels were manually dissected with a scalper starting with the tip cap, pericarp, germ and endosperm. After dissection, the anatomic parts of the kernel were dried in an oven at $60^{\circ} \mathrm{C}$ and weighed in order to calculate the relative kernel-composition expressed as percentage. Endosperm texture was subjectively measured by estimating the relative proportion of hard-vitreous and soft-floury endosperm area on five kernels randomly selected and transversally dissected with a scalper. Granulometry was obtained by grinding the whole grain and passing the resulting meal through 2000, 850, 500, 250 and $180 \mathrm{~m}$ sieves. Fractions were collected, weighted and expressed as percentage (Serna-Saldivar 2010). For physical analysis, kernels were conditioned to 13\% moisture.

\section{Chemical composition and mineral profile}

Determination of chemical composition and mineral profile of the different maize flours was carried out following the procedures established by the AOAC (1998). Analyses were: protein (method 988.05), fat (method 920.39), ash (method 942.05) and crude fibre (method 7070). Phosphorus was determined by the colorimetric method 955.06 and the rest of the minerals by atomic absorption spectroscopy (method 955.09) using a SpectrAA-200 spectrometer (Varian, Australia).

\section{Determination of fatty acids}

The lipid fraction of the ground sample was extracted as described by Folch et al. (1957) using a 2:1 chloroform:methanol solution. Fatty acids were determined using the AOAC (2000) 963.22 standard method with some modifications. Briefly, a CP-3800 gas chromatograph (Varian, USA) equipped with a $30 \mathrm{~m} \times 0.32 \mathrm{~mm} \mathrm{ID,} 0.25 \mathrm{~m}$ Omegawax 320 column (Supelco, USA) and a flame ionization detector (FID) was used. Helium was used as carrier gas at a flow rate of $3 \mathrm{ml} \mathrm{min}^{-1}$. The oven temperature was maintained at 
$140{ }^{\circ} \mathrm{C}$ for $5 \mathrm{~min}$, programmed at a maximum temperature of $240{ }^{\circ} \mathrm{C}$ at a rate of $4{ }^{\circ} \mathrm{C}$ per $1.5 \mathrm{~min}$. Both the injector and detector temperatures were set at $260^{\circ} \mathrm{C}$. For identification and quantification of fatty acids, the retention times of the sample were compared with those of a standard mixture consisting of 37 fatty acid methyl esters (Supelco, USA). The results were expressed in percentage based on the total fat content.

\section{Determination of amino acids}

Amino acid extraction and determination was carried out following the methodology reported by Vazquez-Ortiz et al. (1995). Amino acids were determined using a 9050 high pressure liquid chromatography (Varian, USA) equipped with a 9075 fluorescence detector (Varian, USA) and a $10 \mathrm{~cm} \times 4.6 \mathrm{~mm}$ ID $3 \mathrm{~m}$ ODS RPC C18 column. As a mobile phase, a mixture of solvents was used $(0.1 \mathrm{M}$ sodium acetate buffer $\mathrm{pH}$ 7.2-methanol-tetrahydrofuran in relation 180:19:1 v/v/v) at a flow of $1.5 \mathrm{ml} \mathrm{min}^{-1}$. For quantification and identification of the amino acids contained in the sample, $40 \mathrm{~L}$ of the hydrolysed were mixed with $40 \mathrm{~L}$ of L-alpha-amino butyric acid as internal standard and diluted to one $\mathrm{ml}$ with sodium citrate buffer $\mathrm{pH}$ 2.2. The diluted sample was reacted for $2 \mathrm{~min}$ with o-phthalaldehyde in presence of mercaptoethanol, in order to form highly fluorescent compounds, which were detected using a wavelength of $455 \mathrm{~nm}$ for emission and $340 \mathrm{~nm}$ for excitation. Identification and quantification of amino acids were performed by calibration curves. Glycine-threonine and alanine-tyrosine were quantified together. Results were expressed as grams of amino acids per kilogram of protein.

\section{Determination of lysine, tryptophan and PDCAAS}

Lysine and tryptophan were determined by the colorimetric methods (Galicia et al. 2009), based on 2-chloro-3,5-dinitropyridine and glyoxilic acid reactions, respectively. The amount provided by lysine and tryptophan amino acids was divided by the respective requirements for a 2 to 5 years old infant of 58 and $11 \mathrm{~g}$ of essential amino acids per $\mathrm{kg}$ of protein (FAO/WHO/ONU 1985). Based on these results the Protein Digestibility Corrected Amino Acid Score (PDCAAS) was calculated assuming a protein digestibility of $85 \%$ (Serna-Saldivar et al. 1988).

\section{Statistical analysis}

The experiment was designed as a completely randomised design with three replicates. Differences among variables were determined using Tukey comparison test with a $95 \%$ of confidence. Data were analysed with MINITAB 16 software (Minitab, Inc.). Results are reported on a dry weight (DW) basis.

\section{Results}

\section{Physical properties}

1000-kernel weight of Chalqueno landrace was higher than the rest of the genotypes (Table 1) and similar to some blue maize highland landraces $(>400 \mathrm{~g})$ reported by 

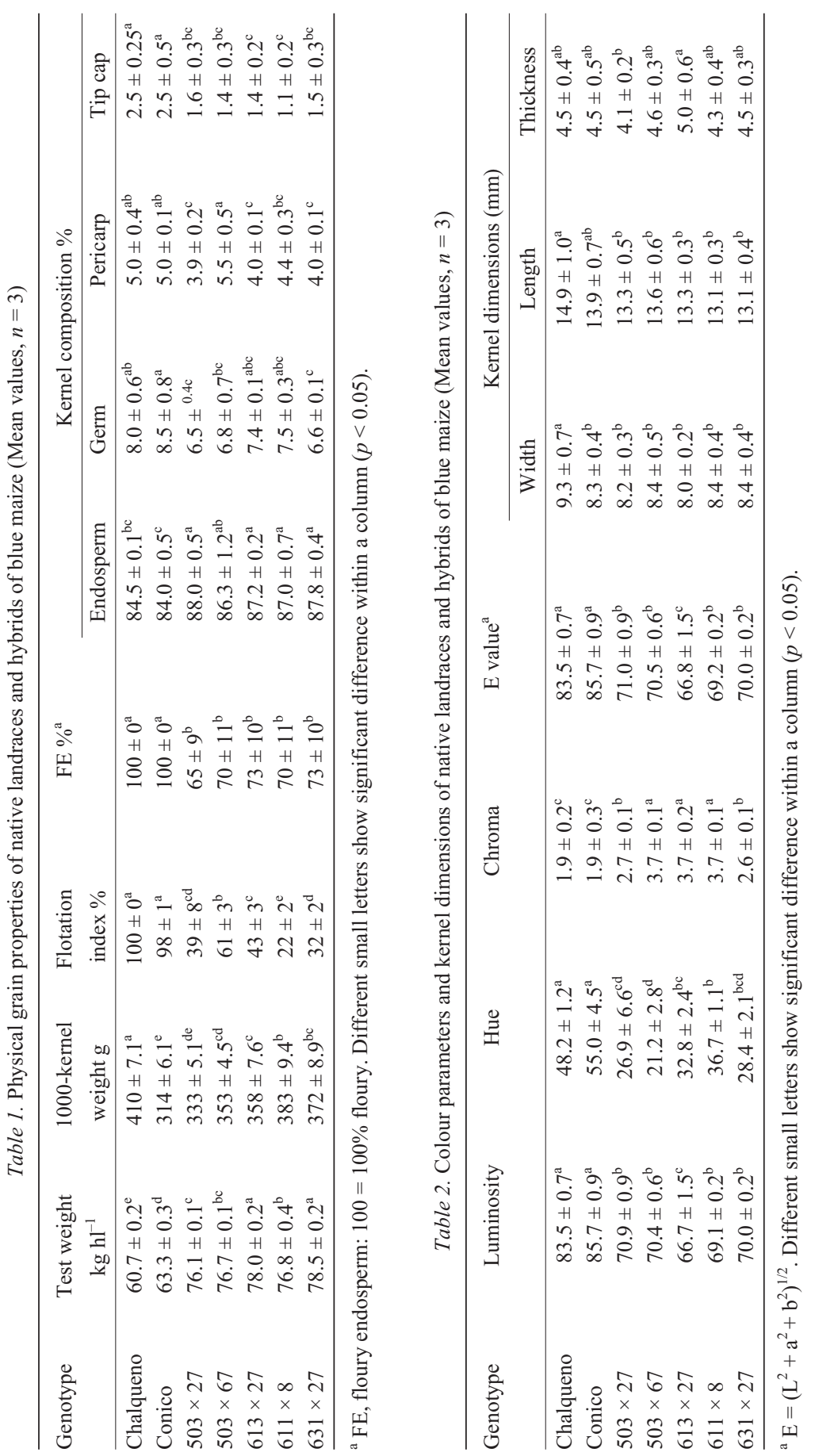

Cereal Research Communications 43, 2015 
Urias-Peraldi et al. (2013). This parameter is an indirect indicator of grain size and correlates with milling yields. According to Serna-Saldivar (2010), large kernels have higher endosperm and lower pericarp proportions. However, Chalqueno also contained the highest proportions of germ, pericarp and tip cap compared to the rest of the kernels, which is undesirable in dry milling and tortilla processes. Also, width, length and thickness dimensions of Chalqueno were highest. Conico landrace had similar dimensions and 1000-kernel-weight values compared to hybrid genotypes. Hybrid genotypes had a significantly higher test weight and lower flotation index compared to the landraces. Endosperm content and endosperm texture showed significant variations among landrace and hybrid genotypes $(p<0.05)$. Generally, hybrid maize had higher proportions of endosperm than landraces.

Hue values of the ground kernels ranged from 21.2 to 55.0 (Table 2). Chalqueno and Conico were significantly different from the hybrid genotypes which contained higher values. For the landraces chroma values were lower (2.6 to 3.7), which indicates that colour intensity of hybrids is greater than in landraces. Regarding the brightness value (L), landraces were significantly brighter than their improved counterparts.

\section{Chemical composition}

Hybrid maize samples $613 \times 27(9.9 \%)$ and $611 \times 8(9.5 \%)$ contained the highest protein. Protein content of Chalqueno, conico, $503 \times 27,613 \times 27$ and $631 \times 27$ genotypes were not significantly different $(8.2$ to $8.8 \%$ ), while $503 \times 67$ contained the lowest protein content (7.3\%). With regard to the fat content, Chalqueno $(4.6 \%)$ and $611 \times 8(4.0 \%)$ contained higher amounts compared to the rest of the samples (3.6 to 3.8\%). Regarding crude fibre content, Chalqueno $(2.7 \%)$ and $613 \times 27(2.5 \%)$ were significantly different $(1.2$ to $1.7 \%)$.

\section{Mineral profile}

$503 \times 67$ had lower levels of minerals compared to values reported by the National Nutrient Database for Standard Reference (USDA 2013) for white corn (1.2\%). After potassium, the major components of the evaluated grains were phosphorus, sodium and magnesium (Table 3). $613 \times 27$ and landraces showed significant difference in phosphorus content. Potassium, magnesium, manganese and zinc contents of hybrid maize were higher than landraces by $15,30,55$ and $41 \%$, respectively. According to USDA (2013), the zinc content in white corn is $22.1 \mathrm{mg} \mathrm{kg}^{-1}$. Iron content of Chalqueno $\left(56 \mathrm{mg} \mathrm{kg}^{-1}\right)$ was significantly different from the rest, which had levels lower than the iron levels than the reported as average value by the USDA (2013) for white corn $\left(27.1 \mathrm{mg} \mathrm{kg}^{-1}\right)$. No significant differences were observed among the evaluated corns in terms of copper content.

\section{Fatty acid profile}

Table 4 shows that the range in the content of unsaturated fatty acids found in all hybrid samples was $79-82 \%$, except for $631 \times 27(75.5 \%)$. This particular maize type contained high levels of arachidic acid (8.8\%). The average fatty acid composition found in all genotypes was $21 \%$ of saturated, $29 \%$ monounsaturated and $50 \%$ polyunsaturated fatty acids. 

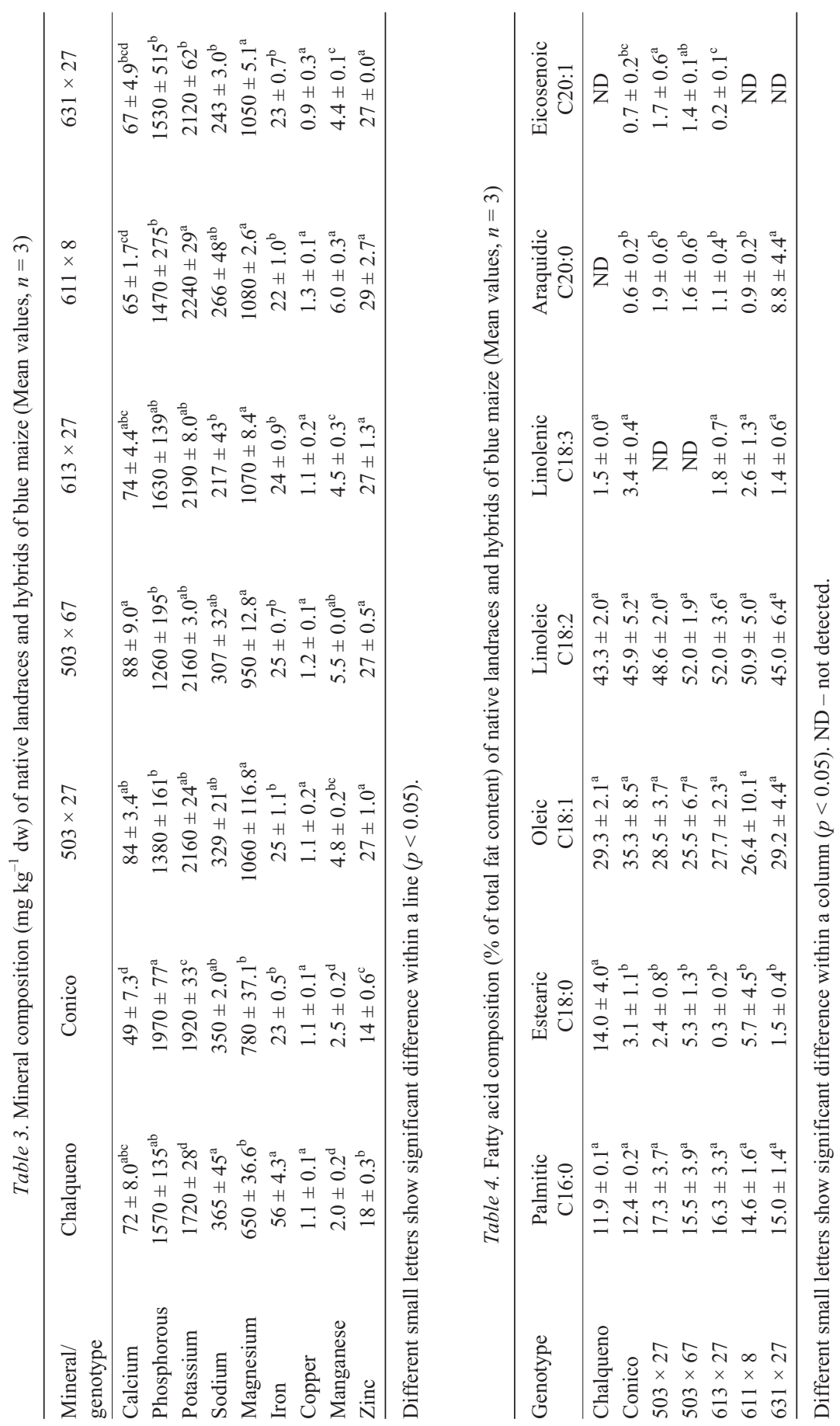

Cereal Research Communications 43, 2015 
Among the saturated fatty acids, palmitic acid (16:0) was the most abundant, except for Chalqueno that comparatively contained 4.6 times more stearic acid (18:0). Approximately $70 \%$ of the fatty acids constituting the triglycerides are composed of oleic (18:1) and linoleic acids (18:2) (Serna-Saldivar 2010). Palmitic (16:0) was the main saturated fatty acid and generally constitutes $15-25 \%$ of the total fat. Moreover, blue corn hybrids $503 \times 67,613 \times 27$ and $611 \times 8$, showed linoleic acid contents above $50 \%$, being close to the mean value established by USDA (2013) for white corn (53\%).

\section{Amino acids profile}

The most abundant amino acids were glutamic acid, alanine, tyrosine, phenylalanine, leucine, glycine, threonine, valine and aspartic acid (Table 5). It was found that hybrids $503 \times 27$ and $503 \times 67$, and Chalqueno contained the highest concentration of predominant amino acids. The average range found in the blue corn was 71.9 to $98.6 \mathrm{~g} \mathrm{~kg}^{-1}$ protein. Chalqueno and $503 \times 67$ also contained the highest tryptophan content. The calculation of the limiting amino acid based on the requirement for a 2 to 5 years old infant was calculated taking into consideration that lysine or tryptophan are the limiting amino acid in corn. For all genotypes the limiting amino acid was lysine except for $503 \times 67$ which limited tryptophan. Therefore, since the average protein digestibility of corn is $85 \%$ (Serna-Saldivar et al. 1988; Sproule et al. 1988), the PDCAAS of Chalqueno and $503 \times 67$ were approximately 20 units better compared to $613 \times 27$ and $611 \times 8$. Conico, $503 \times 27$ and $631 \times 27$ had intermediate PDCAAS values.

\section{Discussion}

\section{Physical properties}

Test weight and flotation index gives an indication of grain health and grain density, respectively. Higher test weight and lower flotation index indicates that properties of landrace genotypes are closely related to their soft-floury endosperm texture. On the contrary, new hybrids have characteristics similar to those desired by nixtamalization and dry milling industries. According to Serna-Saldivar (2010), U.S. No. 2 yellow dent maize is the type most frequently used by millers with optimal test weight of 72.3 to $76.1 \mathrm{~kg} \mathrm{hl}^{-1}$ and 1000-kernel weight greater than 290 g. Endosperm texture evaluation classified the hybrid and landrace genotypes as hard-vitreous and soft-floury, respectively. Most of the blue maize landrace has a soft endosperm which complicates the tortilla process because soft kernels are more prone to yield a sticky dough and staled tortilla. Moreover, hard-vitreous endosperm might act as a physical barrier against insect attack (Serna-Saldivar 2010). It has been found that some blue hybrid maize grown in subtropical environments have similar physical characteristics that are demanded by the tortilla industry (Urias-Peraldí et al. 2013). Regarding colour parameters, the range of chroma value indicates a homogeneous colour appearance of the kernels. Higher hue values of hybrid maizes indicate higher colour purity (Jha 2010). Hue values of 11 to 85 have been previously reported for improved blue maize populations (Urias-Peraldí et al. 2013). 


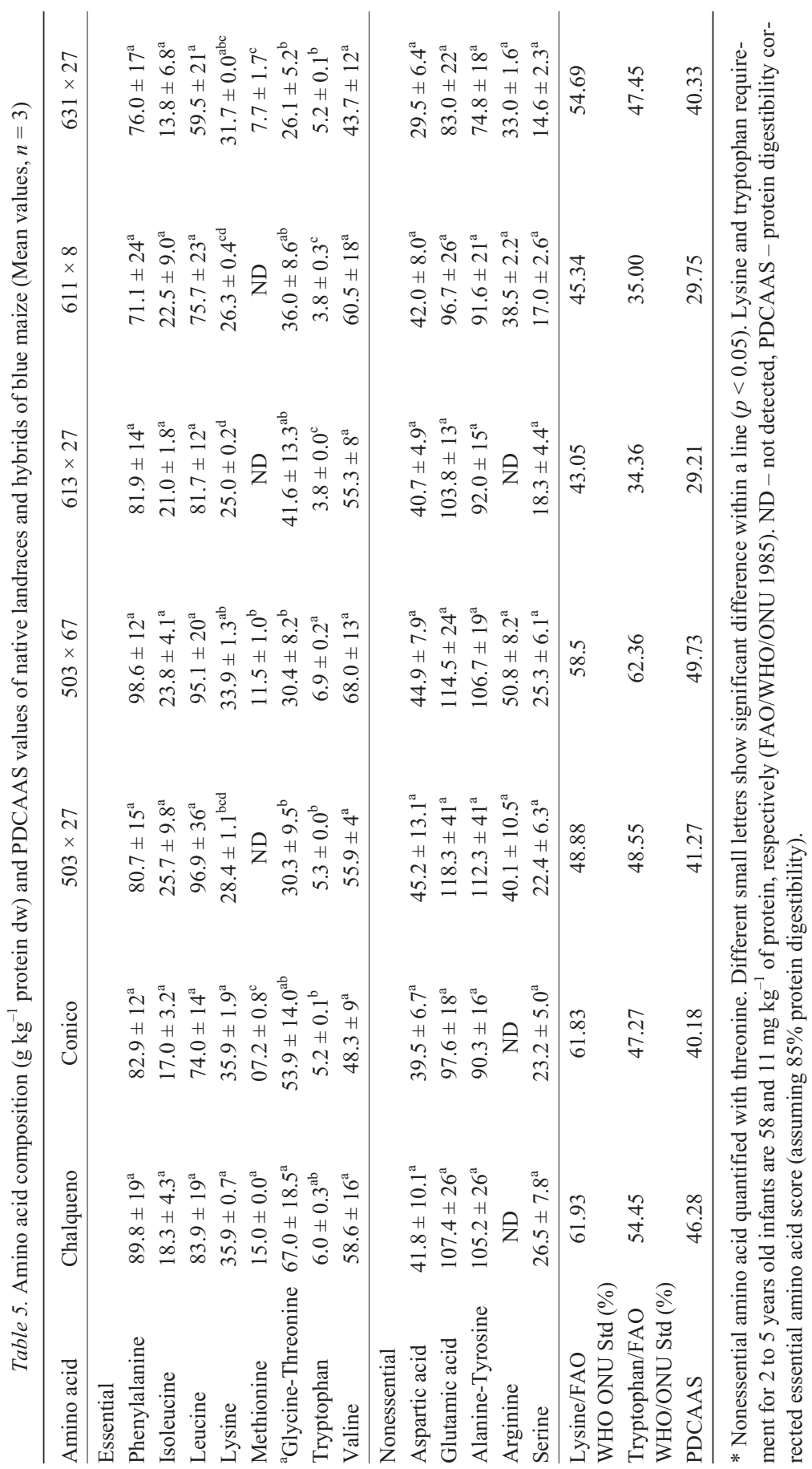

Cereal Research Communications 43, 2015 


\section{Chemical composition}

Chemical composition of $613 \times 27$ and $611 \times 8$ were consistent with the average values established by USDA (2013) and data reported by Serna-Saldívar (2010) for white corn. The variability in the chemical composition found among hybrid and landrace maize could be due to cultural practices, environmental conditions, use of nitrogen fertilization and breeding to which the different crops were exposed, and genetic background (Adom and Liu 2002).

\section{Mineral profile}

The highest level of iron determined for Chalqueno landrace (Table 3) represents about the $30 \%$ of the daily iron intake requirements (DV), based on a caloric intake of 2000 calories, for adults and children of four or more years of age (FDA 2013). Its adequate intake in the diet helps to prevent anemia and strengthens the immune system. Furthermore, high accumulation of zinc inhibits proliferation of malignant prostate cells and induces apoptosis (Feng et al. 2002). Therefore, high levels of zinc in new blue maize hybrids could represent an important source of nutraceutical minerals.

\section{Fatty acid profile}

Fatty acids play a very important role for shelf-life and grain processing. High content of unsaturated fatty acids makes the fat more prone or susceptible to oxidation and rancidity (Serna-Saldivar 2010). Unsaturated fatty acid range found in hybrid kernels was similar to that reported by Preciado-Ortiz et al. (2013) for subtropical maize populations (85\%). Moreover, linoleic acid is considered essential in human nutrition, because from this other important fatty acids such as docosahexaenoic acid (DHA) can be produced and also by their protective effect on cell membrane oxidation (Serna-Saldivar and Abril 2011). Therefore, the high content of linoleic acid in hybrid samples represents an additional advantage in human health and nutrition.

\section{Amino acids profile}

The average value of phenylalanine in normal maize is $48 \mathrm{~g} \mathrm{~kg}^{-1}$ of protein (SernaSaldivar 2010). Higher content in blue maize genotypes could be explained by the involvement of this amino acid in the synthesis of flavonoids, since phenylalanine is the anthocyanin precursor (Taiz and Zeiger 2010). Moreover, in normal corn, the average value for lysine was $27 \mathrm{~g} \mathrm{~kg}^{-1}$ protein and 43 for high-lysine corn (Serna-Saldivar 2010). This data clearly indicates that Chalqueno landrace and $503 \times 67$ had a much better protein quality due to the higher levels of both lysine and tryptophan. Hence, these materials contain a protein quality that resembles more the high lysine or quality protein maize (QPM) which have PDCAAS of approximately 55 to $63 \%$ (Sproule et al. 1988).

From the resulting physical properties, blue maize hybrid could be used in the nixtamalization and dry milling industries. The Chalqueno landrace and hybrid $503 \times 67$ had also better quality protein than the rest of the samples, and a more balanced nutritional value. Although blue maize endosperm lacks of provitamin A compounds, new blue 
maize hybrids could be an important source of nutritional and antioxidant compounds with potential for the food or nutraceutical industry. Furthermore, the use of hybrid maize is an advantage because they offer higher yields compared to the landrace counterparts for highland environments.

\section{Acknowledgements}

We thank Hibridos Lobo, Grupo Ceres and CIMMYT for providing corn samples. Also, we thank Laura Contreras for her technical support and CONACYT for providing funds for scholarship and travelling expenses (Programa Becas Mixtas).

\section{References}

AACC 2000. Approved Methods of the AACC ( $10^{\text {th }}$ ed; 55-10 method). American Association of Cereal Chemists. St. Paul, Minnesota, USA.

Adom, K.F., Liu, R.H. 2002. Antioxidant activity of grains. J. Agric. Food Chem. 50:6182-6187.

AOAC 1998. Official Methods of Analysis ( $16^{\text {th }}$ ed; $988.05,920.39,942.05,955.06,955.09$ methods $)$. Association of Official Analytical Chemist. Arlington, VA, USA.

AOAC 2000. Official Methods of Analysis (1 $7^{\text {th }}$ ed; 963.22 method). Association of Official Analytical Chemist. Arlington, VA, USA.

Beltran, F.J., Bockholt, A.J., Hallauer, A.R. 2001. Blue corn. In: Rooney, L.W. (ed.), Specialty Corns. CRC Press LLC., Forida, USA, pp. 293-301.

Bódi, Z., Pepo, P., Kovács, A., Széles, É., Gyori, Z. 2008. Macro- and microelement contents of blue and red kernel corns. Cereal Res. Commun. 36:147-155.

Castañeda-Ovando, A., Pacheco-Hernández, M.L., Páez-Hernández, M.E., Rodríguez, J.A., Galán-Vidal, C.A. 2009. Chemical studies of anthocyanins: A review. Food Chem. 113:859-871.

Emam, A., Stroshine, R., Tuite, J., Cantone, F., Kirleis, A., Bauman, L., Okos, M. 1981. Evaluating drying rate and grain quality parameters of corn inbreds/hybrids: methodology. Paper 81-3522. Am. Soc. Agric. Eng. St. Joseph, MI, USA, 31 pp. http://eurekamag.com/research/000/881/000881809.p

FAO/WHO/ONU 1985. Energy and Protein Requirements Report of the Joint FAO/WHO/ONU Expert Consultation. Food and Agricultural Organization of the United Nations, World Health Organization and United Nations Organization. WHO Technical Report Series, 724. Geneva, Switzerland.

FAOSTAT 2013. Food and Agricultural Commodities Production. Food and Agricultural Organization of the United Nations Statistics. http://faostat.fao.org/site/339/default.aspx

FDA 2013. Guidance for Industry: A Food Labeling Guide (14. Appendix F: Calculate the percent daily value for the appropriate nutrients). U. S. Food and Drug Administration. http://www.fda.gov/Food/ GuidanceRegulation

Feng, P., Li, T.L., Guan, Z.X., Franklin, R.B., Costello, L.C. 2002. Direct effect of zinc on mitochondrial apoptogenesis in prostate cells. Prostate 52:311-318.

Folch, J., Lees, M., Sloane-Stanley, G.H. 1957. A simple method for the isolation and purification of total lipides from animal tissues. J. Biol. Chem. 226:497-509.

Galicia, L., Nurit, E., Rosales, A., Palacios-Rojas, N. 2009. Laboratory protocols 2008: Maize nutrition quality and plant tissue analysis laboratory. International Maize and Wheat Improvement Center (CIMMYT) Press, Mexico, $42 \mathrm{pp}$.

García-Lara, S., Gutiérrez-Uribe, J.A., Serna-Saldivar, S.O. 2012. Nutraceutical properties of blue maize. In: Jimenez-Lopez, J.C. (ed.), Maize: Cultivation, uses and health benefits. Nova Science Publishers, New York, USA, pp. 113-135.

Harrigan, G.G., Stork, L.G., Riordan, S.G., Reynolds, T.L. 2007. Impact of genetics and environment on nutritional and metabolite components of maize grain. J. Agric. Food Chem. 55:6177-6185.

Jha, S.N. 2010. Colour measurement and modelling. In: Jha, S.N. (ed.), Non-destructive Evaluation of Food Quality. Springer Press. Heidelberg, Germany, pp. 17-40.

Cereal Research Communications 43, 2015 
Lago, C., Cassani, E., Zanzi, C., Landoni, M., Trovato, R., Pilu, R. 2014. Development and study of a maize cultivar rich in anthocyanins: Coloured polenta, a new functional food. Plant Breed. 133:210-217.

Lago, C., Landoni, M., Cassani, E., Doria E., Nielsen, E., Pilu, R. 2013. Study and characterization of a novel functional food: Purple popcorn. Mol. Breed. 31:575-585.

Pandey, M., Verma, R.K., Saraf, S.A. 2010. Nutraceuticals: New era of medicine and health. Asian J. Pharm. Clin. Res. 3:11-15.

Preciado-Ortiz, E.R., García-Lara, S., Ortiz-Islas, S., Ortega-Corona, A., Serna-Saldivar, S.O. 2013. Response of recurrent selection on yield, kernel oil content and fatty acid composition of subtropical maize populations. Field Crops Res. 142:27-35.

Serna-Saldivar, S.O. 2010. Cereal Grains. CRC Press, Florida, USA, 747 pp.

Serna-Saldivar, S.O., Abril, R. 2011. Production and nutraceutical properties of breads fortified with DHA and omega-3 containing oils. In: Preedy, V., Watson, R., Patel, V. (eds), Flour and Breads and their Fortification in Health and Disease Prevention. Academic Press, New York, USA, pp. 313-323.

Serna-Saldivar, S.O., Knabe, D.A., Rooney, L.W., Tanksley, T.D., Sproule, A. 1988. Nutritional value of sorghum and maize tortillas. J. Cereal Sci. 7:83-94.

Shankar, A.H., Prasad, A.S. 1998. Zinc and immune funtion: the biological basis of altered resistance to infection. Am. J. Clin. Nutr. 68(suppl):447-463.

Sproule, A.M., Serna-Saldivar, S.O., Bockholt, A., Rooney, L.W., Knabe, D.A. 1988. Nutritional evaluation of tortillas and tortilla chips from quality protein maize. Cereal Foods World 33:233-236.

Taiz, L., Zeiger, E. 2010. Secondary metabolites and plant defense. In: Taiz, L., Zeiger, E. (eds), Plant Physiology. Sinauer Assoc. Press, Los Angeles, USA, pp. 369-396.

Urias-Peraldí, M., Gutiérrez-Uribe, J.A., Preciado-Ortiz, R.E., Cruz-Morales, A.S., Serna-Saldívar, S.O., García-Lara, S. 2013. Nutraceutical profiles of improved blue maize (Zea mays) hybrids for subtropical regions. Field Crops Res. 141:69-76.

USDA 2013. USDA National nutrient data base for standard reference. United States Department of Agriculture. http://ndb.nal.usda.gov/ndb/search/list.

Vazquez-Ortiz, F.A., Caire, G., Higuera-Ciapara, I., Hernández, G. 1995. High performance liquid chromatography determination of free amino acids in shrimp. J. Liq. Chromatogr. 18:2059-2068.

Wichser, W.R. 1961. The world of corn processing. Am. Miller Process. 89:29-31.

Žilić, S., Serpen, A., Akıllığlu, G., Gökmen, V., Vančetović, J. 2012. Phenolic compounds, carotenoids, anthocyanins, and antioxidant capacity of colored maize (Zea mays L.) kernels. J. Agric. Food Chem. 60:1224-1231. 